\title{
CORRELATION OF THE LEVEL OF SALARIES OF EMPLOYEES IN MEDIUM-SIZED AGRICULTURAL ENTERPRISES AND INDIVIDUAL FARMS AND THE IMPACT ON TOP MANAGEMENT
}

\author{
Jelena Vitomir ${ }^{1}$, Sonja Tomaš-Miskin², Bogdan Laban ${ }^{3}$ \\ *Corresponding author E-mail: slobodan.popovic49@gmail.com
}

A R T I C L E I N F O
Review Article
Received: 14 June2019
Accepted:16 September 2019
doi:10.5937/ekoPolj1903811V
UDC 005.96:[338.43+631.2

Keywords:

individual farm, medium agricultural enterprise, management decisions

JEL: J01, L21, O13

\begin{abstract}
A B S T R A C T
Businesses of an enterprise can be improved in various ways. One of the important influences on the business of agricultural enterprises is maintaining the level of salaries of employees at a competitive level. This was adopted by the authors and a survey was conducted which covered medium-sized agricultural enterprises and individual farms with respect to the level of earnings in the period 2017-2019 in the Republic of Serbia. The results indicate that there is a statistically significant relationship between the level of salaries of employees in both forms of organization of agricultural production and the profit of the enterprise. In addition, there is a significant correlation between the level of employees' salaries and positive profits for 2017 alone $(\mathrm{p}<.05)$, while there is no significant relationship for the remaining two years. Finally, the final conclusion porous from this study suggests that there was an increase in employee pay in 2019 with a simultaneous fall in income.
\end{abstract}

(C) 2019 EA. All rights reserved.

\section{Introduction}

Contemporary management requires the adoption of valid business decisions by the top management or the company's owner. These are general postulates that must be followed by anyone, especially those who decide. Numerous authors highlight various factors that can affect business results, such as those that emphasize the importance of realistic appreciation of anything that can influence management enhancement (Anwar

1 Jelena Vitomir, PhD, Department of finance, Faculty of Business and Finance, University of Business Studies, 78000 Banja Luka, Jovana Dučića 23a, Bosnia and Herzegovina, jelena. vitomir1@gmail.com, ORCID ID https://orcid.org/0000-0001-6995-3297

2 Sonja Tomaš-Miskin, PhD student, Economic School Banja Luka, Banja Luka, Kralja Alfonsa XIII, 78000 Banja Luka, Phone: +387 51 231-250, Bosnia and Herzegovina, sonjat984@gmail.com, ORCID ID: https://orcid.org/0000-0003-3780-9228

3 Bogdan Laban, PhD, City administration of the City Subotica, Trg Slobode 1, 24000 Subotica, Serbia +381 +38124626 888, bogdanl.su@gmail.com, ORCID ID (https:// qa.orcid.org/0000-0002-3730-0125

http://ea.bg.ac.rs 
\& Sun, 2015, Boukalova et al., 2016, Bozzolan et al., 2016, Bratten at al., 2016; Dax \& Oedl-Wieser 2016; Funnell et al., 2016).

This changes structurally the socio-economic conditions of business in the broadest sense (Popović, 2014), which must take into account top management in any branch of business.

Governance issues come to the fore especially in activities that have a smaller turnover of capital over the course of the year, especially in agriculture that has a small turnover ratio during the year. Each change in the conditions in the mentioned activities creates enormous difficulties in decision-making processes, which are pointed out by numerous authors (Brousseau et al., 2014; Durocher \& Gendron, 2014; Catuogno et al., 2016; Florou et al., 2016; Lee, 2019).

Management in agricultural activity must be considered with a particular degree of attention, in which many authors point out in their work (Popović at al., 2015, Kuo et al., 2018, Popović et al., 2018, Novaković et al., 2018). In addition to them and other authors, they emphasize the importance of observing agricultural activity in the broadest context of observation, that is, in the context of global level observations, which are influenced by very heterogeneous factors (Nowak et al., 2016, Wang, 2019, Kijek et al., 2019, Gaetano \& Lamonaca 2019; Balikçioğlu \& Yilmaz 2019).

Management and specific management are of particular importance in the conditions governing agricultural production, where essentially all factors of production come to terms such as land, machinery, labor (Terzić et al., 2019: Bojović at al., 2019). Thus, the comprehensive observation of agricultural production also includes other factors indirectly indicated by authors (Bratkovič-Kregar et al., 2019, Park et al., 2019, Gatarik 2019) in their works.

The issues of labor force evaluation can be seen from multiple levels. One way is to observe from the local level or the region of the state, which they indirectly point out (Kukovič et al., 2016, Scalera, 2016, Alibegović et al., 2018, Rodriguez et al., 2019; ) Chengzhi \& Hao 2019), but also in the context of the framework, for example in the framework public sector of business (Taylor, 2010; Wang, 2016; Naumescu, 2018) or gender and migrants (Mihăilă et al., 2018).

The relationship between evaluation and management is emphasized in numerous papers by the author, with a note of a close relationship with standardization (Cheng, 2016; Tackie et al., 2016; Popović et al., 2017), which must be taken into account when managing the companies (Kouřilová \& Sedláček, 2014; Ege, 2015; Oakes \& Oakes 2015; Catuogno at al., 2016). Essential reporting of management must be comprehensive (Oliveras \& Puig 2005; Williams, 2010; Topac \& Serap 2017), as this is one of the key prerequisites for making business decisions properly.

The authors took into account the views expressed by the authors in the aforementioned papers and outlined the following objectives for the study. The main objective of the author was to show to the expert public the importance of monitoring the level 
of salaries of employees in the broadest form of organizing agricultural production in the Republic of Serbia. The second objective of the author, namely the basic goal, was to determine the movement of employees' wages and profit generation in both forms of agricultural production organization.

Starting from the set goals, the authors made a comparative analysis in order to show the possible differences between the operations of medium-sized agricultural enterprises and individual farms in terms of changes in the level of salaries of employees and profit.

The basic assumption of the author was that there is no difference in the movement of the level of salaries of employees in the analyzed two forms of organization of agricultural enterprises. The authors' focus was on looking at the salaries of employees in the first quarter of the research period. The authors then processed the survey data from the questionnaire. The author's stated goal at this stage of the research was to discover a possible difference between the amounts of earnings of employees in the mentioned forms of agricultural production organization. In the following, the authors wanted to find out, by way of comparison, the trends in the level of earnings of employees in relation to the realized profit.

Bearing in mind their conceptual framework, the characteristics of medium-sized agricultural enterprises and individual farms in terms of the level of wages for the previously defined period and the expected effects based on the available literature, the previously published works on this topic and the intuitive expectations of the authors are formulated in 5 hypotheses.

Hypothesis 1 (H1): There is no change in wage levels for medium-sized enterprises by years for the research period 2017-2019.

Hypothesis 2 (H2): There is no change in the amount of wages in individual farms per year for the research period 2017-2019.

Hypothesis 3 (H3): There is no change in the level of wages between the two observed groups (medium-sized enterprises and individual farms) by age for the research period 2017-2019.

Hypothesis 4 (H4): There is no change in the profit margin of the two observed groups (medium-sized enterprises and individual farms) by age for the research period 2017-2019.

Hypothesis 5 (H5): There is no correlation between the level of wages on the business results achieved by years for both previously defined forms of organization of agricultural production observed for the whole period in which the survey was conducted (2017-2019).

\section{Material and methods used}

To make this work, the authors used a three-year research period in two forms of organization of agricultural production, that is, in farms of individual producers and medium-sized agricultural enterprises. 
The subject of the research was the movement of the amount of wages of workers employed by subjects in two forms of organization that were mentioned by the authors. Medium-sized agricultural enterprises included surveying in 100 entities, and individual farm farms were surveyed with 103 subjects in all three years of observation.

Accordingly, the same number of subjects in the three-year period surveyed by the authors of this paper was surveyed. The observation period ranged from 2017-2019 to the first quarter of the years in question.

Subsequently, the authors deepened the research by performing comparisons for each year within the surveyed subjects with the results achieved in entities in the form of profits that they achieved in the first quarter of the year.

In order to prepare this paper, the authors used the survey because they wanted to obtain reliable information using the research method, through which they could issue valid conclusions on the changes in the wages amount (2017-2019) in the Republic of Serbia in two forms of organization of agricultural production.

Namely, medium-sized agricultural enterprises and individual farms of individual producers were analyzed regarding the movement of wages. By using the questionnaire, the authors came up with valid information regarding the amount of wages in the year of observation, all in the first quarter of the year in question. The aim of the research was to obtain reliable information on the movement of wages levels throughout the observation period (2017-2019).

The results presented in this paper are based on the data processing of 203 surveyed legal entities that operate predominantly in the field of agriculture in the Republic of Serbia. 100 medium-sized agricultural enterprises and 103 farms of individual agricultural producers were surveyed. The information obtained through the survey is approximately the same by the number of surveys for both groups of agricultural production organizations.

The statistical software program SPSS IBM was used for data processing. As an initial insight into the data, descriptive statistics were made, more precisely the arithmetic meanings and standard deviations of the used variables in the sample were calculated, and then the absence of extreme values and the missing data were determined.

Subsequently, in order to gain further insight into the relations of the used indicators, the analysis of the intergroup gap testing ( $\mathrm{t}$-test for independent and dependent samples) was performed in order to gain insight into the changes in the displayed pairs of variables.

For the purposes of the last hypothesis, the authors carried out a correlation analysis (Pirson's correlation coefficient) in order to monitor the correlation between the tested variables. 


\section{Results}

After the introduction of the preliminary reviews, the authors presented the results of the research for the research period 2017-2019. To this end, in order to qualitatively explain the $\mathrm{H}: 1$, which essentially points out the absence of wage changes in mediumsized agricultural enterprises by prior years, H. 2 explained that there was a postulation that there was no change in the amount of wages in individual farms according to the selected For the years in which the survey was conducted, the authors obtained results obtained in Table 1.

Table 1. Values of t-test analysis for medium-sized enterprises and individual farms in relation to the amount of wages

\begin{tabular}{|l|l|c|c|c|c|}
\hline & & Mean & t & df & Sig. \\
\hline \multirow{4}{*}{$\begin{array}{l}\text { Medium-sized } \\
\text { agricultural } \\
\text { enterprises }\end{array}$} & $\begin{array}{l}\text { Wages 2017-Wages } \\
2018\end{array}$ & -486.83838 & -136.492 & 98 & .000 \\
\cline { 2 - 6 } & $\begin{array}{l}\text { Wages 2017-Wages } \\
2018\end{array}$ & -1764.55556 & -509.308 & 98 & .000 \\
\cline { 2 - 6 } & $\begin{array}{l}\text { Wages 2017-Wages } \\
2018\end{array}$ & -1277.71717 & -299.141 & 98 & .000 \\
\hline \multirow{3}{*}{$\begin{array}{l}\text { Individual } \\
\text { farms }\end{array}$} & $\begin{array}{l}\text { Wages 2017-Wages } \\
2018\end{array}$ & -475.14563 & -108.458 & 102 & .000 \\
\cline { 2 - 6 } & $\begin{array}{l}\text { Wages 2017-Wages } \\
2018\end{array}$ & -1766.97087 & -288.789 & 102 & .000 \\
\cline { 2 - 6 } & $\begin{array}{l}\text { Wages 2017-Wages } \\
2018\end{array}$ & -1291.82524 & -154.633 & 102 & .000 \\
\hline
\end{tabular}

Source: authors' calculation

The results of the research based on the $\mathrm{H}$ : 3 setting, i.e. that there is no change in the level of wages between the two observed groups (medium-sized agricultural enterprises and individual farms) by years of research in the period 2017-2019, the authors presented in Table 2.

Table 2. Values of t-test analysis for medium-sized enterprises and individual farms in the amount of wages

\begin{tabular}{|l|c|c|c|}
\hline & t & df & Sig. (2-tailed) \\
\hline Wages 2017 & -.156 & 200 & .876 \\
\hline Wages 2018 & 2.196 & 185.886 & .029 \\
\hline Wages 2019 & -.442 & 200 & .659 \\
\hline
\end{tabular}

Source: authors' calculation

In the continuation of the paper, in order to show the results based on the H: 4 setting, i.e. that there is no change in the amount of profit between the two observed groups (medium-sized agricultural enterprises and individual farms) by the selected years of research in the period 2017-2019, the authors presented the results in Table 3, by displaying the value of the t-test assay. 
Table 3. Values of t-test analysis for medium-sized enterprises and individual farms at the level of profit

\begin{tabular}{|l|l|l|l|}
\hline Profit 2017 & -2.141 & 104.110 & .035 \\
\hline Profit 2018 & -2.643 & 101.834 & .010 \\
\hline Profit 2019 & 3.885 & 191.922 & .000 \\
\hline
\end{tabular}

\section{Source: authors' calculation}

In the end, the authors are in need of $\mathrm{H}: 5$, that is, there is no connection between the movements of the amount of wages to the achieved business results by the selected years of research (2017-2019) for both observed forms of organization of agricultural production presented the results obtained through Table 4.

Table 4. The values of Pirson's correlations between the amount of wages and realized profits in two types of enterprises

\begin{tabular}{|l|l|c|c|c|}
\hline \multicolumn{2}{|c|}{} & Profit 2017 & Profit 2018 & Profit 2019 \\
\hline \multirow{2}{*}{ Wages 2017} & Pearson Correlation & $.240^{* *}$ & $.322^{* *}$ & $-.153^{*}$ \\
\cline { 2 - 5 } & Sig. (2-tailed) & .001 & .000 & .029 \\
\hline \multirow{2}{*}{ Wages 2018 } & Pearson Correlation & .104 & -.030 & -.067 \\
\cline { 2 - 5 } & Sig. (2-tailed) & .139 & .675 & .347 \\
\hline \multirow{2}{*}{ Wages 2019} & Pearson Correlation & -.026 & -.034 & -.039 \\
\cline { 2 - 5 } & Sig. (2-tailed) & .716 & .633 & .583 \\
\hline
\end{tabular}

Source: authors' calculation

\section{Discussion}

The results presented can serve as a basis for obtaining a comprehensive picture when it comes to changing the level of wages in agricultural medium-sized enterprises and individual farms in the period 2017-2019 in the Republic of Serbia.

Based on the values of t-test (Table 1.) for dependent samples, H1 and H2 hypotheses are rejected, as it has been confirmed that there is a significant change in the amount of wages per year, both in medium-sized enterprises and in individual farms (at $\mathrm{p}=$, absolute reliability).

Wages in 2017 are significantly lower than those in the next two years (for both types of enterprises). Also, the wage in 2018 is lower in both types of enterprises than in 2019.

Based on the results obtained in Table 2, i.e. the presentation of the obtained values of the t-test, which was done by the radial analysis of agricultural medium-sized enterprises and individual farms regarding the level of wages, the authors point out that the hypothesis $\mathrm{H}: 3$ is partly rejected.

This is confirmed, based on the value of the t-test for independent samples (Table 2), i.e. there is a difference in the level of wages in 2018 between medium-sized agricultural enterprises and individual farms (medium-sized enterprises have higher wages). 
For the years 2017 and 2019, there is no change in the amount of wages between these two types of enterprises.

Based on the value of the t-test for independent samples (Table 3), the H4 hypothesis is completely rejected, as it has been confirmed that there is a significant difference between the profit in all three years examined between medium-sized aquaculture enterprises and individual farms.

In 2017 and 2018, higher profits were achieved on individual farms than in mediumsized enterprises, while in 2019 the situation was reversed.

At the end of the research, the authors point out that, based on the obtained results of the study of hypothesis 5, it is partially accepted because it is confirmed that the statistically significant association (Table 4) between the wage height and the realized profit is in the positive direction only for 2017 (at the level $\mathrm{p}<.05$ ), while for the remaining two years there is no significant connection. In other words, the increase in wages in 2018 and 2019 did not significantly affect the realized profit, either in a positive or negative direction.

It is noteworthy that in 2019, even though not statistically significant, the relationship changed direction, and the increase in wages led to a decline in profit. This is a potentially significant trend, which requires further monitoring.

\section{Conclusion}

The results presented can serve as a basis for obtaining a comprehensive picture of the level of wages in agricultural medium-sized enterprises and individual farms in the period 2017-2019 in the Republic of Serbia. In the three-year research in the period $2017-$ 2019, the authors analyzed 203 subjects. In the survey, they identified for medium-sized agricultural enterprises (100) and approximately the same number (103) of individual farms. Based on the results shown, the following seven conclusions can be drawn regarding the movement of wages in the most vulnerable part of active agriculture.

First, in the period 2017-2019, there is a significant change in the level of wages in the Republic of Serbia, both in medium-sized enterprises and in individual farms ( $\mathrm{p}=$ $.000)$.

The second conclusion stemming from the study is that wages in 2017 are significantly lower than those in 2018 and 2019, both for the analyzed type of organization of agricultural activity.

Third, wages in 2018 are lower in both types of agricultural activity than in 2019 .

Fourthly, based on the presentation of the results obtained in Table 2, i.e. the presentation of the obtained t-test values, the authors point out that there is a difference in the level of wages in 2018 between medium-sized agricultural enterprises and individual farms (medium enterprises have higher wages). 
Fifth, in 2017 and 2019, there is no change in the amount of wages between mediumsized agricultural enterprises and individual farms.

Sixth, based on the value of the t-test for independent samples (Table 3), the existence of a significant difference between the achieved profit in all three examined years in the observation of medium-sized farms and individual farms was confirmed. In 2017 and 2018, higher profits were achieved on individual farms than in medium-sized enterprises, while in 2019 the situation was reversed.

Seventh, there is a statistically significant linkage (Table 4) between the wage level and the realized profit, i.e. it is in the positive direction only for 2017 (at the level $p<.05$ ), while for the remaining two years there is no significant connection. That is, the increase in wages in 2018 and 2019 did not significantly affect the realized profit, either in positive or negative direction. Meanwhile, as Barker (2018) said: automation will lead to new, better-paying jobs, jobs that will likely be eliminated by robots in the future.

It is noticeable that in 2019 there was an increase in wages and a simultaneous occurrence of declining profits. This is a potentially significant trend, which requires further monitoring in similar researches in the Republic of Serbia as well as in other countries of the former Yugoslavia, as well as in transition countries where similar tendencies are observed.

\section{Acknowledgments}

This study was supported by the Ministry of Education, Science and Technological Development of the Republic of Serbia, and was created as a result of the projects: \& quot; TR31025 \& quot; and bilateral project (Montenegro and Serbia; 2019-2020): \& quot; Alternative cereals and oil crops as a source of healthcare food and an important raw material for the production of befoul \& quot; and FAO project: \& quot; Redesigning the exploitation of small grains genetic resources towards increased sustainability of grain-value chain and improved farmers \& \#39; livelihoods in Serbia and BulgariaGRAINEFIT; 2019-2021\& quot.

\section{Conflict of interests}

The authors declare no conflict of interest.

\section{References}

1. Alibegović, D., Hodžić, S. \& Bečić, E. (2018): Limited Fiscal Autonomy of Croatian Large Cities. Lex Localis - Journal of Local Self-Government, 16(1): 107-128.

2. Anwar, S. \& Sun, S. (2015): Taxation of labour income and the skilled-unskilled wage inequality. Economic Modelling, 47: 18-22 https://doi.org/10.1016/j.econmod.2014.12.037

3. Bratkovič-Kregar, T., Antončič, B. \& Ruzzier, M. (2019): Linking a multidimensional construct of networking self-efficacy to firm growth. Economic Research-Ekonomska Istraživanja, 32(1): 17-32. https://doi.org/10.1080/133167 $\underline{7 X .2018 .1545594}$ 
4. Balikçioğlu, E. \& Yilmaz, H. (2019): How fiscal policies affect credit rates: probity analysis of three main credit rating agencies' sovereign credit notes. Transylvanian Review of Administrative Sciences, 56: 5-22 http://rtsa.ro/tras/index.php/tras/ article/view/585/571

5. Bojović, R., Popović, V., Ikanović, J., Živanović, Lj., Rakaščan, N., Popović, S., Ugrenović, V \& Simić, D. (2019). Morphological characterization of sweet sorghum genotypes acrossen vironments, The J. Anim. Plant Sci. 29(3):2019. http:// www.thejaps.org.pk/docs/Accepted/2019/29-03/04.pdf

6. Boukalova, K., Kolarova, A. \& Lostak, M. (2016): Tracing shift in Czech rural development paradigm (Reflections of Local Action Groups in the media). Agricultural Economics (Zemédělská ekonomika), 62: 149-159 https://doi. org/10.17221/102/2015-AGRICECON

7. Bozzolan, S., Laghi, E. \& Mattei, M. (2016): Amendments to the IAS 41 and IAS 16 - implications for accounting of bearer plants. Agric. Econ. - Czech. 62: 160166. https://doi.org/10.17221/48/2015-AGRICECON

8. Bratten, B., Jennings, R. \& Schwab, C. (2016): The accuracy of disclosures for complex estimates: Evidence from reported stock option fair values. Accounting, Organizations and Society. 52: 32-49. https://doi.org/10.1016/j.aos.2015.09.001

9. Brousseau, C., Gendron, M., Belanger, P. \& Coupland, J. (2014): Does fair value accounting contribute to market price volatility? An experimental approach. $\underline{A c-}$ counting \& Finance. 54(4): 1033-1061. https://doi.org/10.1111/acfi.12030

10. Catuogno, S., Arena, C., Saggese, S., Sarto, F. (2016): The Influence of Blockholders, Bondholders and Families on the Venturers' Accounting Behavior. International Journal of Business and Management. 11(8): 31-43. https://www.researchgate. net/publication/305487345

11. Chengzhi, Y. \& Hao, S. (2019): Impact of municipal political decision makers' turnover on the degree of building and land use in china: an empirical study based on the profiles of the secretaries of municipal party committees, Transylvanian Review of Administrative Sciences, 56: 132-148 http://rtsa.ro/tras/index.php/tras/ article/view/585/571

12. Cheng, C. (2016): Discussion of 'IFRS non-GAAP earnings disclosures and fair value measurement'. Accounting \& Finance, 56(1): 99-112. https://onlinelibrary. wiley.com/doi/pdf/10.1111/acfi.12206

13. Connolly-Barker, M. (2018). Advanced Automation Technology, Labor Market Insecurity, and Collective Joblessness: The Determinants, Constraints and Employment Effects of Robots and Artificial Intelligence on the Realm of Work. Psychosociological Issues in Human Resource Management, 6(2), 92-97.

14. Dax, T. \& Oedl-Wieser, T. (2016): Rural innovation activities as a means for changing development perspectives an assessment of more than two decades of promoting LEADER initiatives across the European Union. Studies in Agricultural Economics, 118, 30-37 https://doi.org/10.7896/j.1535 
15. Durocher, S. \& Gendron, Y. (2014): Epistemic commitment and cognitive disunity toward fair-value accounting. Accounting and Business Research. 44(6): 630-655. https://doi.org/10.1080/00014788.2014.938012

16. Gatarik, E. (2019): The value of knowledge sharing in decision-making and organisational development: a model-theoretic systemic analysis of an intervention in an Austrian S.M.E. Economic Research-Ekonomska Istraživanja. 32(1): 148-167. https://doi.org/10.1080/1331677X.2018.1552175

17. Ege, M. S. (2015): Does internal audit function quality deter management misconduct?. The Accounting Review, 90(2): 495-527. https://doi.org/10.2308/accr-50871

18. Gaetano, S. \& Lamonaca, E. (2019): On the drivers of global grain price volatility: an empirical investigation. Agric. Econ. - Czech, 65: 31-42 https://doi. org/10.17221/76/2018-AGRICECON

19. Florou, A., Kosi, U., Popoe, P. (2016): Are international accounting standards more credit relevant than domestic standards?. Accounting and Business Research. 46(7): 1-29. https://doi.org/10.1080/00014788.2016.1224968

20. Funnell, W., Wade, M., R. Jupe. (2016): Stakeholder perceptions of performance audit credibility. Accounting and Business Research. 46(6): 601-619. https://doi.or g/10.1080/00014788.2016.1157680

21. Kourrilová, J. \& Sedláček, J. (2014): Environmental accounting and the FADN as a basis of model for detecting the material flow cost accounting. Agric. Econ. Czech., 60: 420-429. https://www.agriculturejournals.cz/publicFiles/79 2013-AGRICECON.pdf

22. Kijek, A., Kijek, T., Nowak A. \& Skrzypek, A. (2019): Productivity and its convergence in agriculture in new and old European Union member states. Agric. Econ. - Czech, 65: 01-09 https://doi.org/10.17221/262/2017-AGRICECON

23. Kukovič, S., Haček, M. \& Bukovnik, A. (2016): The Issue of Local Autonomy in the Slovenian Local Government System, Lex Localis - Journal of Local Self-Government, 14(3): 303-320. http://pub.lex-localis.info/index.php/LexLocalis/article/ view/14.3.303-320\%282016\%29

24. Kuo, K., Lee, C. \& Wu, S. (2018): environmental policy and labour market imperfection. Bulletin of Economic Research, 70: 175-184 https://doi.org/10.1111/ boer. 12122

25. Lee, J. (2019): Regional heterogeneity among non-operating earnings quality, stock returns, and firm value in biotech industry. Agric. Econ. - Czech, 65: 10-20 https:// doi.org/10.17221/24/2018-AGRICECON

26. Mihăilă, R., Gregova, E., Janoskova, K., Kolencik, J., \& Arsene, A. M. (2018). The instrumental function of gendered citizenship and symbolic politics in the social construction of labor rights for migrants. Journal of Research in Gender Studies, 8(2), 124. 
27. Naumescu, V. (2018): Administrative and political perspectives of the EU's reform: focus on permanent structured cooperation. Transylvanian Review of Administrative Sciences, 2018/Special Issue, 56: 60-74. http://rtsa.ro/tras/index.php/tras/article/view/585/571

28. Novaković, S., Vukasović, D., Laban, B.,Ivić, M., Popović, V. \& Popović, S. (2018). Managing agricultural company by using internal control and significance of risk presentation, Economics of Agriculture, 2: 801-812. doi:10.5937/ekoPolj1802801N

29. Nowak, A., Janulewicz, P., Krukowski, A. \& Bujanowicz-Haraś, B. (2016): Diversification of the level of agricultural development in the member states of the European Union. Cahiers Agricultures, 25: 55004 https://doi.org/10.1051/cag$\underline{\mathrm{ri} / 2016040}$

30. Oakes, H. \& Oakes, S. (2015): An analysis of business phenomena and austerity narratives in the arts sector from a new materialist perspective. Accounting and Business Research, 45(6-7): 738-764. https://doi.org/10.1080/00014788.2015.108 $\underline{1555}$

31. Oliveras, E. \& Puig, X. (2005): The Changing Relationship between Tax and Financial Reporting in Spain. Accounting in Europe, 2: 195-207. https://doi. org/10.1080/09638180500379020

32. Park, E., Kang, J., Choi, D. \& Han, J (2019): Effects of initial public offerings on economic performance of small and medium-sized enterprises. Economic Research-Ekonomska Istraživanja, 32(1): 85-100. https://doi.org/10.1080/133167 7X.2018.1545595

33. Popović, S. (2014). Socio-economic factors limiting the development of agrarian, Feljton, Novi Sad. [in Serbian: Popović, S. (2014). Socio-ekonomski faktori ograničenja razvoja agrara, Feljton, Novi Sad].

34. Popović, S., Majstorović, A. \& Grublješić Ž. (2015). Valuation of facilities in use and application of international accounting standards, Actual problems of economics, 3(165): 379-387. https://eco-science.net/en/downloads

35. Popović, S., Novaković, S., Đuranović, D., Mijić, R., Grublješić, Ž, Aničić, J. \& Majstorović, A. (2017): Application of international accounting standard-16 in a public company with predominantly agricultural activities. Economic ResearchEkonomska Istraživanja, 30(1): 1850-1864. https://doi.org/10.1080/133167 7X.2017.1383171

36. Popović, S., Đuranović, D., Laban, B., Ivić, M., Jovin, S., Nastić, S., Grublješić, Ž. \& Popović, V. (2018). Impact of different light intensity on the production of the plant narcissus 1. and its financial effects, Economics of Agriculture, 4: 1359-1370. doi:10.5937/ekoPolj1804359P

37. Rodriguez, M., Miguel, Sanchez, L., Cejudo, E. \& Antonio, C. (2019): Variety in local development strategies and employment: LEADER programme in Andalusia. Agric. Econ. - Czech, 65: 43-50 https://doi.org/10.17221/106/2018-AGRICECON 
38. Scalera, F. (2016): The Balkan Area Development: Threats and Opportunities for Italian Companies' Investment Strategies. International Journal of Business and Management, 11(10): 37-50. DOI:10.5539/ijbm.v11n10p37

39. Taylor, J. (2010): Public service motivation, civic attitudes and actions of public, nonprofit and private sector employees: Public Administration, 88(4): 1083-1098. https://doi.org/10.1111/j.1467-9299.2010.01870.x

40. Tackie, G., Mrafo-Yiadom, E. \& Achina, S. (2016): Determinants of Internal Audit Effectiveness in Decentralized Local Government Administrative Systems. International Journal of Business and Management, 11(11): 184-195. DOI:10.5539/ ijbm.v11n11p184

41. Terzić, D., Popović, V., Malić, N, Ikanović, J, Rajičić, V., Popović, S., Lončar, M \& Lončarević. V. (2019). Effects of long-term fertilization on yield of siderates andorganic matter content of soil in the process of recultivation. The J. Anim. Plant Sci. 29(3):2019. http://www.thejaps.org.pk/docs/Accepted/2019/29-03/12.pdf

42. Topcu, M. \& Serap Çoban, S. (2017): Financial development and firm growth in Turkish manufacturing industry: evidence from heterogeneous panel based noncausality test. Economic Research-Ekonomska Istraživanja, 30(1): 1758-1769. https://doi.org/10.1080/1331677X.2017.1383179

43. Wang, W. (2016): Exploring the determinants of network effectiveness: The case of neighbourhood governance networks in Beijing. Journal of Public Administration Research and Theory, 26(2): 375-388. https://doi.org/10.1093/jopart/muv017

44. Wang, D. (2019): Manufacturing and agricultural pollution, private mitigation and wage inequality in the presence of pollution externalities. Agric. Econ. - Czech, 65: 51-58 https://doi.org/10.17221/79/2018-AGRICECON

45. Williams, C. (2010). Principles of management, DataStatus, Belgrade. [in Sebian: Williams, C. (2010). Principi menadžmenta, DataStatus, Beograd]. 